\title{
Benign tracheo-gastric fistula: A case which occured 23 years after total laryngopharyngoesophagectomy.
}

Benign trakeo-gastrik fistül: Total laringofaringö̈zefajektomiden 23 yıl sonra gelişen bir olgu.

Bayram Metin*, Olgun Kadir Arıbaş, İzzet Özgür Özlük, Burhan Apillioğulları, Emre Özkan

Department of Chest Surgery (Bayram Metin, MD), Bozok University School of Medicine, TR66200 Yozgat, Department of Chest Surgery (O. K. Arıbaş, MD), Gazi University School of Medicine, TR-06560 Ankara, Ear, Nose and Throat Clinic (İ. Ö. Özlük, MD), Zonguldak State Hospital, TR-67100 Zonguldak, Department of Chest Surgery (B. Apillioğulları, MD), Necmettin Erbakan University Meram School of Medicine, TR-42080 Konya, Chest Diseases Clinic (E. Özkan, MD), Balıkesir State Hospital, TR-10000 Balıkesir

\begin{abstract}
Benign tracheo-neo-esophageal (Gastric) fistula, which occuring after total esophagectomy and laryngectomy, is a rare but life-threatening complication. Tracheo-esophageal fistula and valvevoice prosthesis are used as alternative to the artificial larynx for laryngectomy patients. Fistula symptoms have been occurred due to the erosion formed of gastric acid around the prosthesis within the fistula area in our case.
\end{abstract}

Keywords: Esophagectomy, laryngectomy, fistula

\section{Özet}

Total özefajektomi ve lerenjektomiden sonra gelişen benign trakeo-yeni-özefagial (Gastrik) fistül nadir fakat yaşamı tehdit eden bir komplikasyondur. Larenjektomili hastalarda trakeo-özefageal fistül ve ses valf protezleri ses oluşturmada larenkse alternatif olarak kullanılırlar. Bizim vakamızda fistül alanında protezin etrafında mide asidine bağlı oluşan erozyon nedeni ile fistül semptomları gelişmiştir.

Anahtar sözcükler: Özefajektomi, larenjektomi, fistül

Geliş tarihi/Received: 23 Aralık 2013; Kabul tarihi/Accepted: 13 Mayıs 2014

*Corresponding author:

Dr. Bayram Metin, Gögüs Cerrahisi Anabilim Dalı, Bozok Üniversitesi Tıp Fakültesi, TR-66200

Yozgat. Email: drbaymet@ hotmail.com 


\section{Introduction}

Benign gastrotracheal fistula (BGF) is a rare but life-threatening situation. This fistula may be formed by the development of tracheal erosion around gastric suture or erosion around tracheostomy tube, endotracheal hyperinflation due to tube balloon, preoperative radiotherapy, gastric tube ulcers, anastomotic failure and the local inflammatory process failure in trachea and esophagus or mediastinum. In addition, fistula progresses due to the tracheal devascularization of a large mediastinal lymph node dissection [1, 2]. In this article we present a patient with total esophagectomy whose tracheo-gastric fistula is formed by the erosion around voice prosthesis insert area by gastric acid and therefore aspiration symptoms develop

\section{Case report}

A 54 years old male patient with hypopharynx CA underwent a surgery 23 years ago with laryngectomy and esophagectomy and servical gastro-esophageal anastomosis. Tracheogastric fistula was performed in order to provide voice and then the voice prosthesis device was attached to this area. The patient hasn't suffered any complication until recently but he had cough due to the aspiration after meals in the last 3 months. The integrity between the trachea and esophagus was impaired in the posterior region of tracheostomy orifice tissue and the fistula which was formed in between was indicated with chest CT. In Esofagogastroscopy the cricopharyngeal sphincter and the vocal cords weren't observed at the entrance of esophagus. When we advanced approximately $10 \mathrm{~cm}$ in the single-lumen we came across Z-line and the gastric pillar. When we advanced approximately $4-5 \mathrm{~cm}$ in the stomach, $3 \mathrm{~cm}$ diameter ulcer surrounded by hyperemic, edematous white exudates, were seen. Exudation, tracheal fistula in the middle of the mouth was $2 \mathrm{~cm}$ in diameter. Biopsies were taken around the fistula. There was no malignancy in biopsy results. There was tracheo-gastric fistula $2 \mathrm{~cm}$ after tracheostomy orifice in fiberoptic bronchoscopy. Preoperative preparations were completed and then the patient underwent an operation. When we approached trachea and esophagus with left cervical incisions, it was examined as complicated with a tracheo-gastric fistula on the posterior wall of trachea which was $1 \mathrm{~cm}$ under tracheostomy orifice. Trachea was seperated from esophagus by fistulectomy procedure. Serosa and mucosa of the stomach were sutured in the double layer after debridement of the necrotic remnant in stomach. The periphery of the fistula area was sutured after primary closure of the fistula on the trachea. The surgical procedure was finished after the control of the bleeding was done. The patient started oral feeding and was discharged without complications on the postoperative tenth day. The patient has been observed without problems in postoperative three years. 


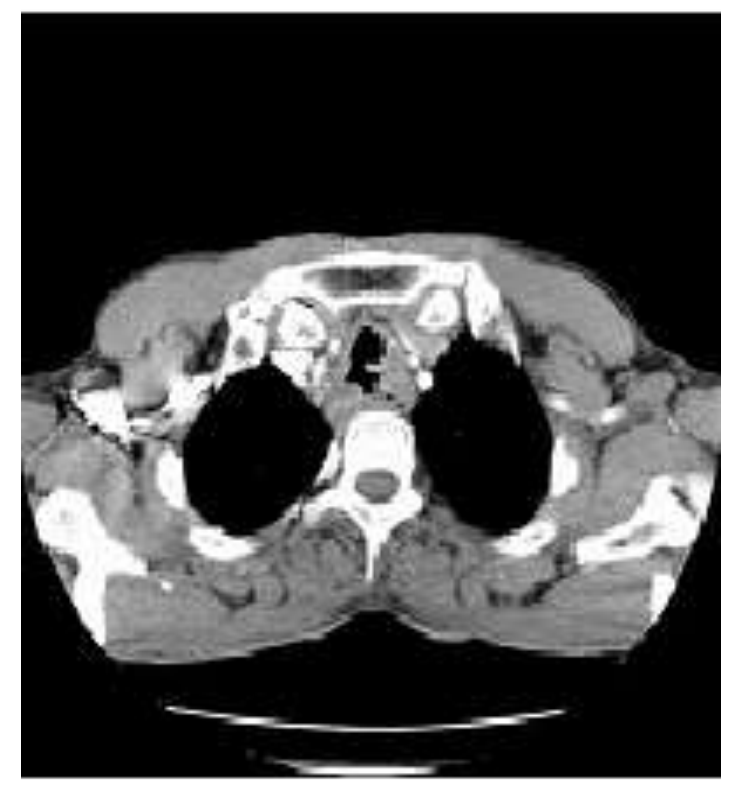

Figure 1. Tracheogatric fistula view in Chest CT.

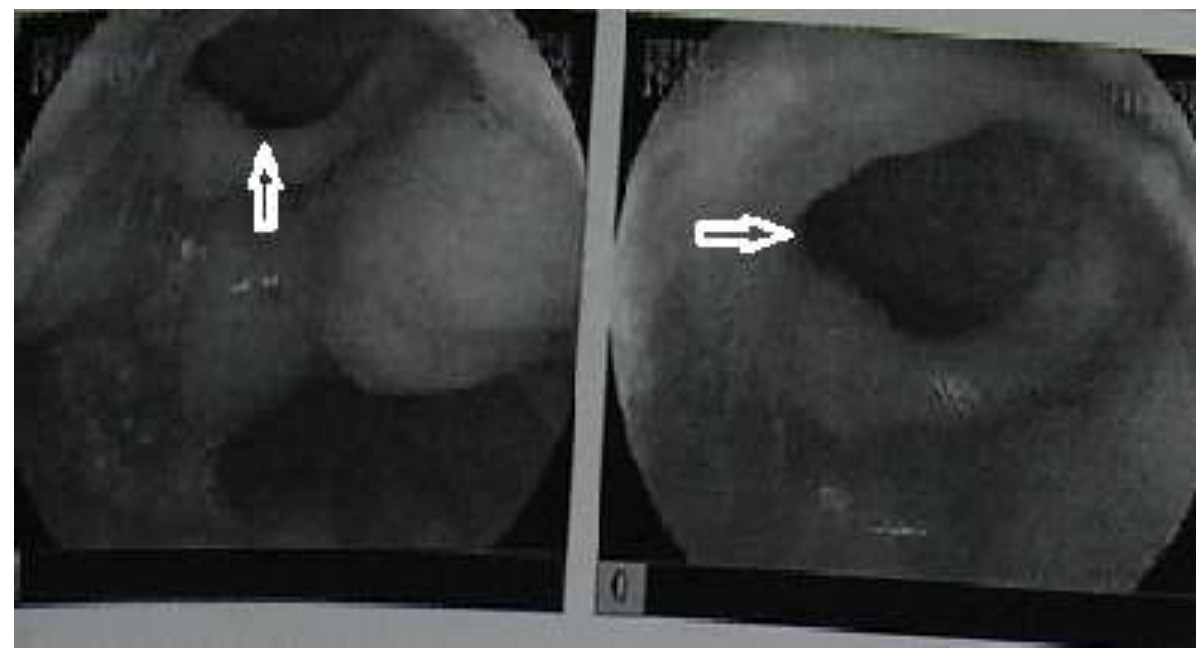

Figure 2. View of the fistula area by esophagoscopy.

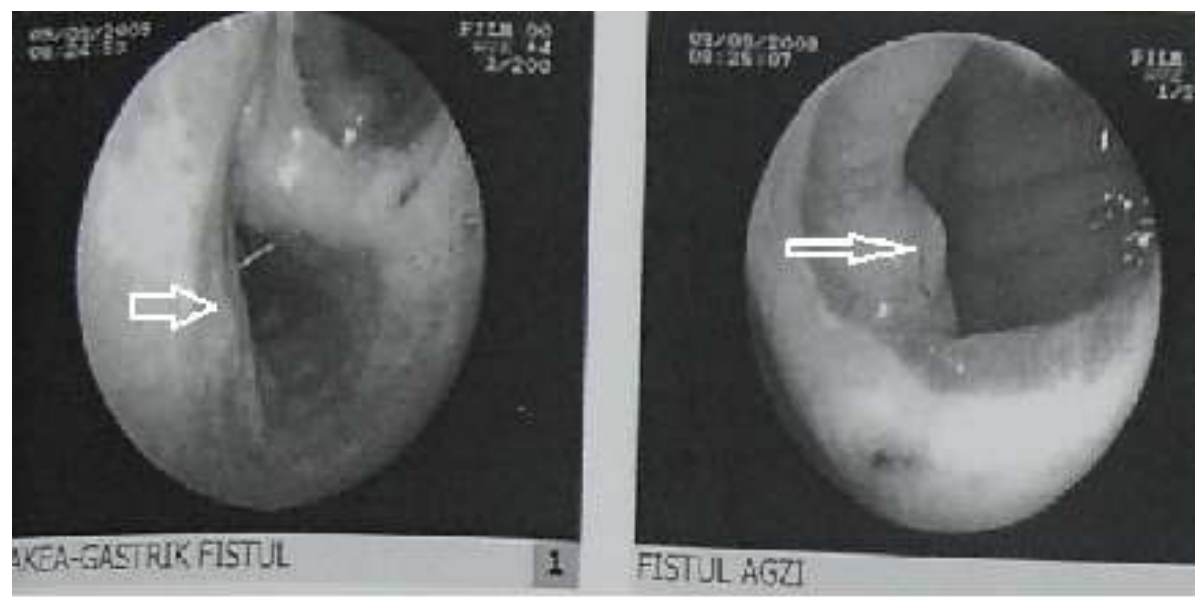

Figure 3. View of the fistula area by Bronchoscopy. 


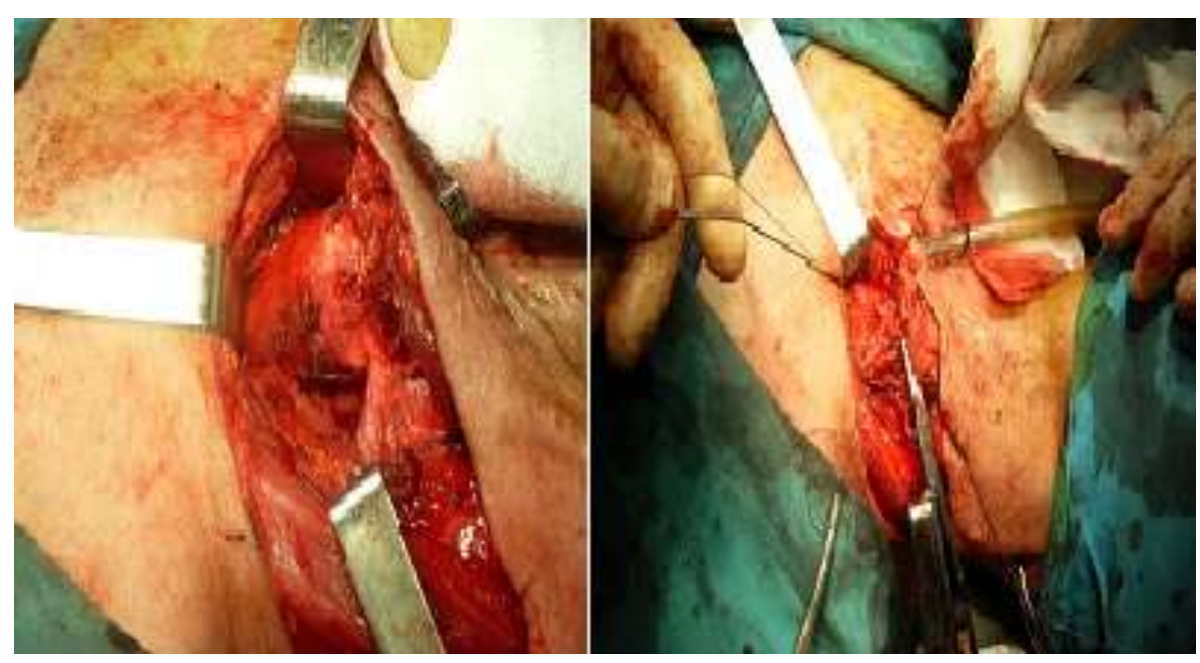

Figure 4a, b. a; trachea separated from esophagus by performing fistulectomy, b; after surrounding necrotic gastric spaces were debrided, ostium of fistula was closed by double layer suturing the gastric walls serosal and mucosal component. Tracheal site of fistula was closed by primary repair.

\section{Discussion}

Esophageal reconstruction is a complicated procedure. The most serious complication after esophagectomy is an anastomosis leak. Tracheoesophageal fistula is one of the rare but critical complications. This fistula can be caused by tracheal erosion forming at gastric suture line, erosion occurance at tracheostomy tube site, endotracheal hyperinflation caused by cuff, preoperative radiation therapy, gastric tube ulcers, anastomosis insufficiency and local inflamatory process insufficiency in trachea, mediastinum or new esophagus [1, 2].

Esophageal fistulas are generally presented with dyspnea related to increased tracheal secretion, acute respiratory distress, aspiration pneumonia, cough attacs after oral feeding and spitting of gastric content. As there are various reasons of aspiration in the patients with esophegeal replacement, it may be difficult to distinguish the exact cause from the others. Early diagnosis is accepted as life saving issue in these cases. Showing the air fluid level below the fistula level at posteroanterior chest graphy can be demonstrative. Many studies suggest that barium contrast graphy is an effective practice to determine the fistula. Exact diagnosis can be done by Esophagostroboscopy and bronchoscopy with indicating the defective area. Endoscopy is a useful procedure for localisation of fistula. However it can cause diffuculty to see a small defect at gastric mucosa. In such cases bronchoscopy usage is more effective than endoscopy [1,2].

Treatment of benign trachea neoesophegal fistula after esophagectomy is individualized by the site and size of fistula and severity of accompanying symptoms. Conservative treatment may be considered in the first place but presence of symptoms of mediastinitis and serious lung infections cause surgical treatment inevitable. Conservative therapy consists of ceasing the oral feeding and antibiotic therapy [3]. Furthermore, obliteration with endoscopic fibrin glue and hemostatic clips is defined as a succesful procedure in the literature. Tracheal or esophageal defect is closed directly after surgical tracheotomy. Omental and pleural patch or muscle fleb can be moved on to defective area to prevent the fistula recurrence. Colonic interposition methods can be utilized if neo-esophageal tract might not be supplied with gastrointestinal tract [2, 3]. In our case trachea is separated from esophagus by performing fistulectomy. Debrided ostium of fistula was closed by double layer suturing the serosal and mucosal component of gastric walls after surrounding necrotic gastric spaces. Tracheal site of fistula was closed by primary repair. 
Tracheoesophageal fistula is formed on purpose to obtain voice in the patient who has a laryngectomy. These patients are supposed to use a voice prosthesis which should fit in fistula and this prosthesis has a non-return valve system that protects the respiratory system during swallowing and provides positive pressure and causes air to get into esophagus and produce voice. Numerous voice prosthesis are developed to be placed into tracheoesophageal fistula. Some of them are Blom-Singer, Panje, Shapiro-Rananthan, Colorado, Herman, Provox, Groningen, Voicemaster. Most common used ones are provox, Blom singer and Voicemaster nowadays. These prosthesis have a non-return valve system which protects the respiratory system during swallowing and helps to produce voice by pushing the air into esophagus with positive pressure. Our patient has one frequent complication of such systems which is the widening of the tracheogastric fistula area with erosion caused by gastric secretions and aspiration development $[4,5]$. Therefore, we do not recommend voice prosthesis application with tracheaesophageal fistula after esophagectomy.

\section{References}

1. Kalmar K, Molnar TF, Morgan A. Non-malignant tracheo-gastric fistula following esophagectomy for cancer. European Journal of Cardio-thoracic Surgery 2000; 18: 363-5.

2. Buskens CJ, Hulscher JB, Fockens P. Benign tracheo-neo-esophageal fistulas after subtotal esophagectomy. Ann Thorac Surg 2001; 72: 221-4.

3. Song S-W, Lee H-S, Kim MS. Republic of Korea. Repair of gastrotracheal fistula with a pedicled pericardial flap after Ivor Lewis esophagogastrectomy for esophageal cancer. J Thorac Cardiovasc Surg 2006; 132: 716-7.

4. Trussart C, Lawson G, Remacle M. Voice prostheses: Long-term follow-up retrospective study (three-to sixteen-year follow-up of 22 patients). Rev Laryngol Otol Rhinol (Bord) 2003; 124: 299-304.

5. İmre A, Pınar E, Çallı Ç, Umut E.Complications of tracheoesophageal puncture and speech valves: Retrospective analysis of 47 patients. Kulak Burun Bogaz Ihtis Derg 2013; 23: 15-20. 